\title{
Isolation and screening of fungi from rotten wood for various hydrolytic enzymes production
}

\author{
Dimple Tanwar, Nivedita Sharma, Nisha Sharma and Prashant Kumar Prusty \\ Microbiology Laboratory, Department of Basic Sciences, Dr. Y. S. Parmar University of Horticulture and Forestry, Nauni-Solan-173223, Himachal Pradesh, India
}

\section{Article Info}

Article history

Received 3 April 2020

Revised 23 May 2020

Accepted 26 May 2020

Published online 30 June 2020

Keywords

Cellulase

Xylanase

Laccase

Rotten wood

Submerged fermentation

\begin{abstract}
In the present study, rotten wood samples were collected from different sites of Solan, Shimla, Sirmour, Kangra and Chamba districts of Himachal Pradesh and 52 fungal isolates were isolated. Out of 52 fungal strains, 25 isolates were found to be positive for laccase activity, 31 isolates showed cellulase activity, out of which maximum zone size was observed. Ligninolytic fungal isolates exhibited multiple hydrolytic enzyme activity of laccase, cellulase and xylanase and different strains were selected on the basis of highest zone of hydrolysis surrounding fungal colonies. In case of quantitative screening, maximum laccase production was observed in $\mathrm{S} 7(1.22 \mathrm{IU} / \mathrm{ml})$ where as $\mathrm{S} 5$ obtained maximum cellulase of $0.793 \mathrm{IU} / \mathrm{ml}$ and SH5 produced appreciable amount of xylanase $(8.09 \mathrm{IU} / \mathrm{ml})$.
\end{abstract}

\section{Introduction}

Lignocellulosic biomass is a promising renewable resource for attaining value added products. Lignocellulosic biomass is mainly composed of cellulose, hemicellulose and lignin distributed within the cell walls. Structural component of these cellulose, hemicelluloses and lignin differ with species, tissues and maturity of the plant cell wall. Many micro-organisms are capable of producing a variety of lignocellulolytic enzymes, i.e., laccase, cellulase and xylanase which are responsible for the biodegradation of lignocellulosic wastes in nature (Acharya et al., 2010). Recently, the environment friendly and cost effective approach of microbial pretreatment has received attention of researchers for enhancing enzymatic saccharification of lignocellulosic biomass. This method employs micro-organisms which degrade lignin, the most recalcitrant polymer in biomass through the action of lignin degrading enzymes (Barakat et al., 2013). Generally, micro-organisms especially fungi have capability to produce or excrete the hydrolytic enzyme in the nature. The degradation of wood by fungi occurs through different biochemical mechanisms.

Lignolytic fungi overall help in complete decomposition of lignocellulosic waste and convert it into value added products by synergetic action of three groups of enzymes, i.e., cellulase, xylanase and laccase (Dwivedi et al., 2011). The filamentous fungi are richer in the production of extracellular lignocellulolytic enzymes as compared to bacteria and yeast. Since, today's world demand for

Corresponding author: Dr. Nisha Sharma

Microbiology Laboratory, Department of Basic Sciences, Dr. Y. S. Parmar University of Horticulture and Forestry, Nauni-Solan-173223, Himachal Pradesh, India

E-mail: sharma.nisha11685@gmail.com

Tel.: +99-9459078111

Copyright (C) 2020 Ukaaz Publications. All rights reserved.

Email: ukaaz@yahoo.com; Website: www.ukaazpublications.com more constant, active and specific enzymes, wood decaying fungi serve as an ideal candidate for the management of lignocellulosic wastes. The degradation of biomass and its subsequent bioconversion into ethanol may be attributed to the synergistic and complementary action of many enzymes including hydrolytic enzymes laccase, cellulase and xylanase as well as enzymes from yeasts for fermentation (Nagraj et al., 2014). Ligninolytic microbial systems and their enzymes were more applicable to improve the digestibility and nutritive value of animal feeds, degradation of toxic pollutants and bioconversion of lignin into useful organic compounds and to increase the fermentability of lignocellulosic residues and also for the commercial production of biofuels from feed stock, paper pulp. So, the present study was initiated with the aim of isolation and screening of potential ligninolytic fungi from rotten wood samples collected from different forests.

\section{Materials and Methods}

\subsection{Collection and enrichment of samples}

Rotten wood samples were collected from different sites rich in pine forests of Himachal Pradesh, i.e., Solan, Shimla, Kangra, Chamba and Sirmour districts. To the $5 \mathrm{~g}$ of rotten wood sample, $2 \%$ of cellulose powder was added and water was sprinkled in the petriplates to maintain an adequate level of moisture. The petriplates containing the above mixture were incubated at $28 \pm 2{ }^{\circ} \mathrm{C}$ for $4-5$ days.

\subsection{Isolation of ligninolytic, cellulolytic and xylanolytic fungi}

One gram of enriched sample was serially diluted from $10^{-2}$ to $10^{-8}$ times using sterilized $9 \mathrm{ml}$ dilution blanks. Each of diluent $(0.1 \mathrm{ml})$ was placed on the surface of Potato Dextrose Agar (PDA) medium and incubated at $28 \pm 2{ }^{\circ} \mathrm{C}$ for 3 days. The pure cultures were obtained by bit method respectively. 
2.3 Qualitative screening of ligninolytic, cellulolytic and xylanolytic fungi

An extensive screening of fungal isolates capable of exhibiting appreciable levels of ligninolytic cellulolytic and xylanolytic, activity was done. The plates showing growth after $48 \mathrm{~h}$ of incubation were subjected to qualitative screening for visualizing corresponding zones of hydrolysis of different isolates for assessing their potential to produce multiple carbohydrate, i.e., laccase, cellulase and xylanase.

\subsubsection{Laccase activity (Kalra et al., 2013)}

Fungal isolates were cultured on petriplates containing potato dextrose agar (PDA) supplemented with $0.04 \%$ guaiacol. In addition, $0.01 \%(\mathrm{w} / \mathrm{v})$ chloramphenicol was also added to the media to avoid bacterial growth and the $\mathrm{pH}$ of the medium was adjusted to 5.5 with $1 \mathrm{~N} \mathrm{HCl}$. The plates were incubated at $28 \pm 2{ }^{\circ} \mathrm{C}$ for 5 days. Clear reddish brown colored zones could be observed only around colonies of the active fungal strains.

\subsubsection{Cellulase and xylanase activity (Sreedevi et al., 2013)}

Detection of cellulase and xylanase activity was done on the culture plate of cellulose hydrolysis (containing $1 \%$ cellulose powder) as well as xylan hydrolysis ( $1 \%$ xylan powder) media, the plates were flooded with iodine solution ( $1 \%$ iodine crystals and $2 \%$ potassium iodide) and allowed to stand for $15 \mathrm{~min}$ at room temperature, a bluish black complex with cellulase and xylanase demarcated a clear zone around the colonies.

2.4 Quantitative screening of ligninolytic, cellulolytic and xylanolytic fungi

Enzymes production: Different fungal cultures were grown in Potato dextrose agar media containing petriplates at $28 \pm 2{ }^{\circ} \mathrm{C}$. As soon as full plate of fungal isolates was observed, $10 \mathrm{ml}$ of autoclaved distilled water was poured and scratched. The spore suspension thus formed was containing $1 \times 10^{7}$ spores $/ \mathrm{ml}$, five $\mathrm{ml}$ of fungal inoculum was added to each $100 \mathrm{ml}$ of laccase production broth amended with $0.04 \%$ guaiacol for laccase, Riviere's broth containing $1 \%$ cellulose for cellulase and $1 \%$ xylan for xylanase in $250 \mathrm{ml}$ of Erlenmeyer flasks and incubated for 7 days at $28 \pm 2{ }^{\circ} \mathrm{C}$ at $120 \mathrm{rpm}$. After incubation, the culture contents were centrifuged at $10,000 \mathrm{rpm}$ for $15 \mathrm{~min}\left(4^{\circ} \mathrm{C}\right)$ and the supernatant was collected and enzyme assays were performed.

\subsubsection{Enzyme assays}

\subsubsection{Laccase assay (Rehan et al., 2016)}

The reaction mixture contained $1 \mathrm{ml}$ of $2 \mathrm{mM}$ of guaicol in $3 \mathrm{ml}$ sodium acetate buffer ( $\mathrm{pH} 5.5)$ and $1 \mathrm{ml}$ of enzyme supernatant was added. The blank was also prepared with all components except the enzyme. The reaction mixture was incubated at $30^{\circ} \mathrm{C}$ for 15 min. The absorbance was read at $450 \mathrm{~nm}$.

\subsubsection{Cellulase assay (Reese and Mandel, 1963)}

The sub-enzymes of cellulase were measured by following standard assays. CMCase activity was determined by incubating $0.5 \mathrm{ml}$ of culture supernatant with $0.5 \mathrm{ml}$ of $1.1 \% \mathrm{CMC}$ in citrate buffer $(0.05 \mathrm{M}, \mathrm{pH} 5.0)$ at $500 \mathrm{C}$ or $1 \mathrm{~h}$. After incubation and $3 \mathrm{ml}$ of $3,5-$ dinitrosalicylic acid (DNSA) reagent was added. The tubes were immersed in boiling water bath and removed after $15 \mathrm{~min}$. The optical density was read at $540 \mathrm{~nm}$. FPase activity was measured by Reese and Mandel method. The reaction containing $0.5 \mathrm{ml}$ of culture supernatant, $50 \mathrm{mg}$ strips of filter paper (Whatmann no.1) and $0.5 \mathrm{ml}$ of citrate buffer $(0.05 \mathrm{M}, \mathrm{pH} 5.0)$ was incubated at $50^{\circ} \mathrm{C}$ for $1 \mathrm{~h}$. After incubation and $3 \mathrm{ml}$ of DNS reagent was added. The tubes were boiled in boiling water bath and removed after $15 \mathrm{~min}$. The OD was read at $540 \mathrm{~nm}$. For $\beta$-glucosidase activity the reaction mixture containing $1 \mathrm{ml}$ of $1 \mathrm{mM} \mathrm{p}$-nitrophenol $\beta$-D-glucopyranoside in $0.05 \mathrm{M}$ acetate buffer ( $\mathrm{pH} 5.0$ ) and $100 \mu \mathrm{l}$ of enzyme solution was incubated at $450 \mathrm{C}$ for $10 \mathrm{~min}$. After incubation, $2 \mathrm{ml}$ of $1 \mathrm{M}$ $\mathrm{Na}_{2} \mathrm{CO}_{3}$ was added and the mixture was heated in boiling water bath for $15 \mathrm{~min}$ and OD was read at $400 \mathrm{~nm}$.

\subsubsection{Xylanase assay (Miller, 1959)}

To $0.5 \mathrm{ml}$ of xylan, $0.3 \mathrm{ml}$ of citrate buffer (pH 5) and $0.2 \mathrm{ml}$ of enzyme was added. The reaction mixture was incubated at $45^{\circ} \mathrm{C}$ for $10 \mathrm{~min}$ and then $3 \mathrm{ml}$ of DNSA reagent was added and the mixture was then heated on boiling water bath for $15 \mathrm{~min}$, after cooling down at room temperature absorbance of reaction mixture was read at $540 \mathrm{~nm}$.

\subsubsection{Reducing sugars (Miller, 1959)}

To $1.0 \mathrm{ml}$ of culture supernatant, $3 \mathrm{ml}$ of DNSA reagent was added and the mixture was then heated on boiling water bath for $15 \mathrm{~min}$, after cooling down at room temperature, absorbance of the reaction mixture was read at $540 \mathrm{~nm}$.

\subsubsection{Protein assay (Lowry et al., 1951)}

To $0.1 \mathrm{ml}$ of culture supernatant, $2.5 \mathrm{ml}$ of Lowry's alkaline reagent was added and allowed to stand for $10 \mathrm{~min}$. After incubation diluted $(1 \mathrm{~N})$ Folin Ciocalteau's reagent $(0.25 \mathrm{ml})$ was added. The contents were shaken quickly and allowed to stand for $30 \mathrm{~min}$ for maximum colour development. Absorbance of reaction mixture was read at $670 \mathrm{~nm}$.

\subsection{Statistical analysis}

The data recorded for different parameters were subjected to Completely Randomized Design (Gomez and Gomez, 1976). The statistical analysis based on mean value of replications used for each treatment was made using analysis of variance (ANOVA) for Completely Randomized Design.

\section{Results}

3.1 Isolation of hydrolytic enzymes producing fungi

Different sources, viz., rotten wood samples with a high probability of enzymes, i.e., laccase, cellulase, xylanase producing fungi were collected from different sites of Solan, Shimla, Sirmour, Kangra and Chamba districts of Himachal Pradesh (Figure 1). In total, 52 fungal strains were isolated from rotten wood samples in PDA medium, pH 5.6 enlisted in Figure 2 (a-d) along with their morphological properties. Out of 52 fungal strains, 26 were isolated from Solan district, 6 from Shimla district, 11 from Sirmour district and 1 fungal strain was isolated from Kangra and 1 from Chamba district of Himachal Pradesh. These isolates were tentatively 
identified on the basis of their mycelium appearance, colour and texture as Trichoderma sp., Fusarium sp., Penicillum sp., Rhizopus sp., and Aspergillus sp. As depicted in Figure 2 (a), the sites of collection of rotten wood samples showed a great variation of fungal population amongst different sites, i.e., $14 \%$ collected from Rajgarh, $8 \%$ from Giripul, $14 \%$ from Nauni, $12 \%$ from Shoghi, $14 \%$ from Sultanpur, $10 \%$ from Arki, 14\% from Kasauli, 2\% from Chamba and Kangra. Figure 2(b) showed variation in the colour of different fungal strains and varied from $40 \%$ white, $25 \%$ green, $26 \%$ black, $3 \%$ light brown and light black in colour. Figure 2(c) depicted the mycelium of the isolates, out of total, $54 \%$ were filamentous, $34 \%$ short hyphae, $8 \%$ long hyphae and $4 \%$ network of hyphae. Figure 2(d) showed the texture of isolated fungi, where $64 \%$ were rough, $5 \%$ feathery, $19 \%$ mucilaginous, $6 \%$ spreading type and slightly slimy in texture. Rotten wood is a rich habitat of potential lignocellulolytic enzymes producing fungi as these enzymes help in the degradation of wood. Thus, isolation of hyperligninolytic, hypercellulolytic and hyperxylanolytic fungi had been done in the present study from the rotten wood considering it a valuable niche of fungi for biodegradation. Mahmood et al. (2016) isolated Coniphora puteana and Daedalea dickinsii on the dead trunk of Ficus carica collected from Rawalpindi, Islamabad, Murree and Bagh Azad Kashmir. Ferdes et al. (2018) isolated five fungal strains namely Pleurotus ostreates, Polyporus squamosus, Lentinula ododes, Hypsizygus terrulatus and Flammulina velutipies known for the production of wood degrading enzymes. Thirty four mesophilic as well as thermophilic fungal species were isolated from different sources like decaying wood, compost and soil (Kaur and Gupta, 2016). Chayal and Agarwal (2016) isolated 6 endophytic fungi from leaves of Cupressus torulosa. Alsohaili and Hasan (2018) isolated filamentous fungi from soil samples of different geographical locations in the north eastern desert in Jordan.
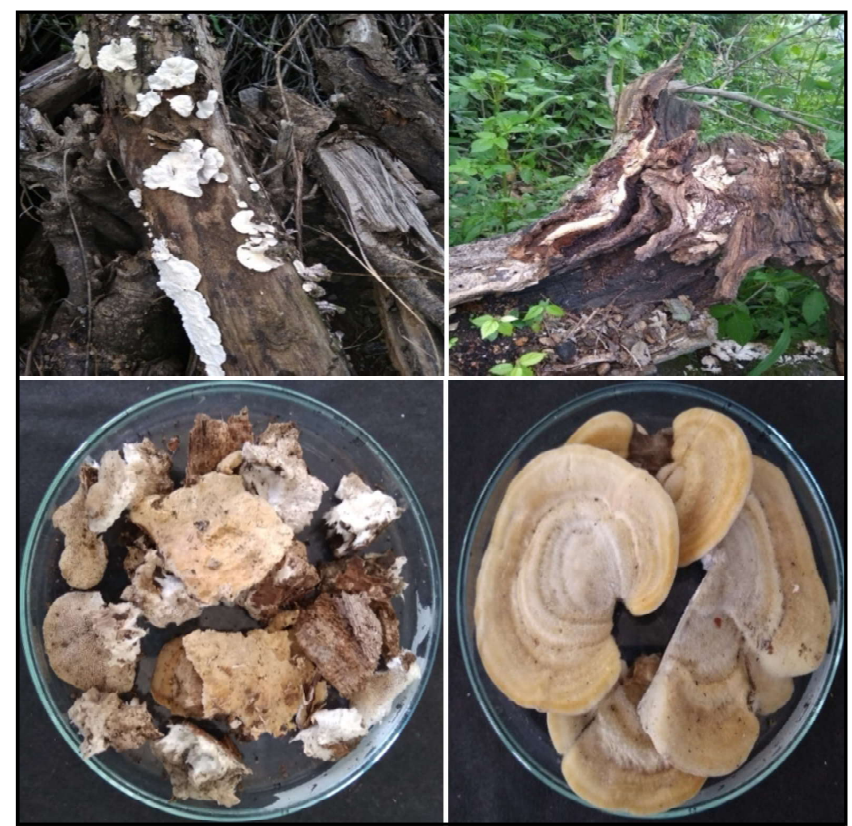

Figure 1: Collection of rotten wood samples from different sites.

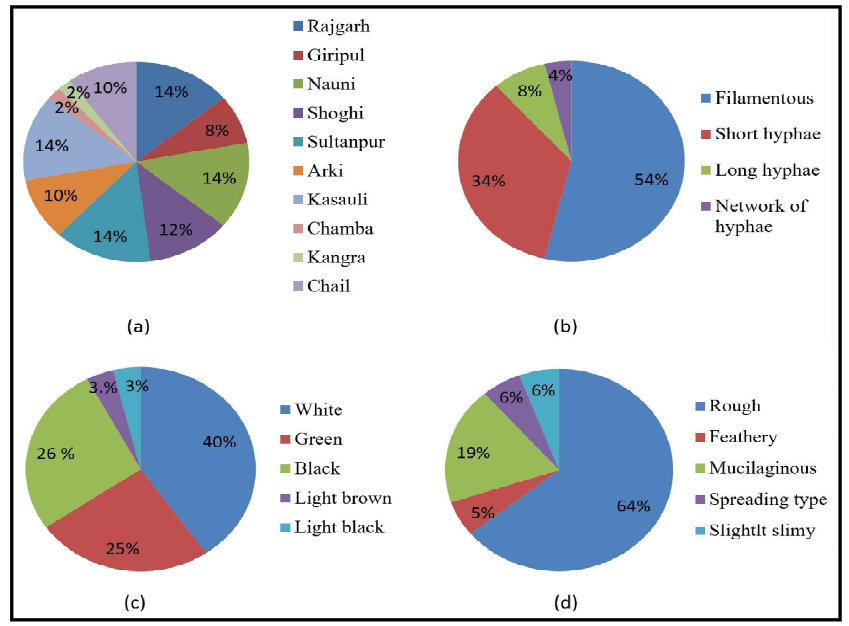

Figure 2: Morphological Characteristics of fungal Isolates (a) sites, (b) mycelium, (c) colour and (d) texture.

\section{Discussion}

4.1 Qualitative screening of ligninolytic, cellulolytic and xylanolytic fungal isolates

An extensive screening of fungal isolates capable of exhibiting appreciable levels of lignolytic, cellulolytic and xylanolytic activities was done (Table 1 and Figure 3). Figure 3 (a) showed positive activity of laccase on PDA medium where guaicol was used as an indicator. A reddish brown coloured zone surrounding fungal colonies was observed after 5 days of incubation. Out of 52 isolates, 25 isolates were found to be positive for laccase activity. As the results depicted in Table 1, maximum zone size was shown by five isolates, i.e., $\mathrm{S} 7(20 \mathrm{~mm}), \mathrm{R} 4(19 \mathrm{~mm}), \mathrm{SH} 2(18 \mathrm{~mm}), \mathrm{K} 3(16 \mathrm{~mm})$ and $\mathrm{S} 5(15 \mathrm{~mm})$ and minimum zone was observed in SH1, i.e., $2 \mathrm{~mm}$. Figure $3 \mathrm{~b}$ and $3 \mathrm{c}$ showed the activity of cellulase and xylanase on Reverie's medium containing cellulose/xylan as a substrate. The plates showing growth after $48 \mathrm{~h}$ of incubation were subjected to qualitative screening for visualizing corresponding zones of hydrolysis of different isolates showing their potential to produce multiple carbohydrate, i.e., laccase, cellulase and xylanase. 31 isolates showed cellulase activity, out of which maximum zone size was observed in six isolates, i.e., R4 (29 mm), S7 (28 mm), K3 (28 mm), R4 (26 mm), SH5 (26 mm), S5 (24 mm) and SH2 (22 mm) and minimum zone was observed by $\mathrm{N} 7$, i.e., $4 \mathrm{~mm}$. On the other hand, 31 isolates showed xylanase activity, out of which maximum zone size was observed in six isolates, i.e., $\mathrm{S} 7(32 \mathrm{~mm}), \mathrm{K} 3(30 \mathrm{~mm}), \mathrm{S} 5(28 \mathrm{~mm}), \mathrm{SH} 5$ (28 mm), SH5 (26 mm), R4 and A4 (24 mm). Minimum zone, i.e., $12 \mathrm{~mm}$ was observed in N7 and R1 isolate (Table 2). Ligninolytic fungal isolates exhibited multiple hydrolytic enzyme activity of laccase, cellulase and xylanase and different strains were selected on the basis of highest zone of hydrolysis surrounding fungal colonies. Nayak et al. (2017) screened 23 lignocellulolytic fungi qualitatively by guaiacol plate assay on potato dextrose agar medium. Out of 23 fungal strains, five fungal isolates showed maximum qualitative laccase production. Vantamuri and Kaliwal (2015) isolated 150 fungal strains and only 8 isolates had the ability to produce laccase. Out of which, one isolate, i.e., FS6 was presumed to be potent, another (FS1) showed medium potency and six isolates (FS2, FS3, FS4, FS5, FS7 and FS8) showed weak laccase producing ability. 56 fungal isolates were screened for 
ligninolytic activities. Strains showing significant colored zone around the growing mycelia were particularly considered as potential ligninolytic enzyme producers and selected for quantitative determination of the laccase enzyme (Megersa et al., 2017). Pingli et al. (2017) screened 84 fungal strains for their ability to produce cellulase, out of which, 12 isolates were identified and selected for quantitative screening. Ramanjaneyuleo et al. (2015) studied xylanase activity in the form of zone of hydrolysis in the range of $20 \mathrm{~mm}$ to 90 $\mathrm{mm}$ and the isolates with greater than $50 \mathrm{~mm}$ of hydrolytic zone were further assessed for the production of xylanase enzyme.

Table 1: Qualitative Screening of fungal isolates isolated from rotten wood samples for hydrolytic enzyme production

\begin{tabular}{|c|c|c|c|c|c|c|c|}
\hline \multirow[t]{2}{*}{ Sr. No. } & \multirow[t]{2}{*}{ Isolate Name } & \multicolumn{2}{|c|}{ Laccase enzyme } & \multicolumn{2}{|c|}{ Cellulase enzyme } & \multicolumn{2}{|c|}{ Xylanase enzyme } \\
\hline & & Activity & Zone size $(\mathrm{mm})$ & Activity & Zone size $(\mathrm{mm})$ & Activity & Zone size $(\mathrm{mm})$ \\
\hline 1 & R1 & $+\mathrm{ve}$ & 9.00 & -ve & 0.00 & $+\mathrm{ve}$ & 12.00 \\
\hline 2 & $\mathrm{R} 2$ & -ve & 0.00 & $+\mathrm{ve}$ & 28.00 & $+\mathrm{ve}$ & 0.00 \\
\hline 3 & R3 & -ve & 0.00 & $+\mathrm{ve}$ & 22.00 & $+\mathrm{ve}$ & 10.00 \\
\hline 4 & R4 & $+\mathrm{ve}$ & 19.00 & $+\mathrm{ve}$ & 20.00 & $+\mathrm{ve}$ & 28.00 \\
\hline 5 & R5 & $+\mathrm{ve}$ & 6.00 & $-v e$ & 0.00 & $-v e$ & 0.00 \\
\hline 6 & R6 & $+\mathrm{ve}$ & 4.00 & $+\mathrm{ve}$ & 28.00 & $+\mathrm{ve}$ & 0.00 \\
\hline 7 & R7 & $+\mathrm{ve}$ & 6.00 & -ve & 0.00 & -ve & 0.00 \\
\hline 8 & SH1 & $+\mathrm{ve}$ & 2.00 & -ve & 0.00 & $+\mathrm{ve}$ & 18.00 \\
\hline 9 & $\mathrm{SH} 2$ & $+\mathrm{ve}$ & 16.00 & $+\mathrm{ve}$ & 22.00 & $+\mathrm{ve}$ & 19.00 \\
\hline 10 & SH3 & -ve & 0.00 & -ve & 0.00 & -ve & 0.00 \\
\hline 11 & SH4 & -ve & 0.00 & $+\mathrm{ve}$ & 20.00 & $+\mathrm{ve}$ & 13.00 \\
\hline 12 & SH5 & + ve & 10.00 & $+\mathrm{ve}$ & 24.00 & $+\mathrm{ve}$ & 24.00 \\
\hline 13 & SH6 & -ve & 0.00 & -ve & 0.00 & -ve & 0.00 \\
\hline 14 & $\mathrm{C} 1$ & -ve & 0.00 & -ve & 0.00 & $+\mathrm{ve}$ & 18.00 \\
\hline 15 & $\mathrm{C} 2$ & -ve & 0.00 & -ve & 0.00 & -ve & 0.00 \\
\hline 16 & $\mathrm{C} 3$ & -ve & 0.00 & $-v e$ & 0.00 & $-v e$ & 0.00 \\
\hline 17 & $\mathrm{C} 4$ & -ve & 0.00 & $+\mathrm{ve}$ & 12.00 & -ve & 0.00 \\
\hline 18 & $\mathrm{C} 5$ & $+\mathrm{ve}$ & 8.00 & -ve & 0.00 & -ve & 0.00 \\
\hline 19 & K1 & $-v e$ & 0.00 & $+\mathrm{ve}$ & 18.00 & $+\mathrm{ve}$ & 20.00 \\
\hline 20 & $\mathrm{~K} 2$ & -ve & 0.00 & -ve & 0.00 & -ve & 0.00 \\
\hline 21 & $\mathrm{~K} 3$ & $+\mathrm{ve}$ & 18.00 & $+\mathrm{ve}$ & 28.00 & $+\mathrm{ve}$ & 23.00 \\
\hline 22 & K4 & -ve & 0.00 & -ve & 0.00 & -ve & 0.00 \\
\hline 23 & K5 & $+\mathrm{ve}$ & 6.00 & -ve & 0.00 & -ve & 0.00 \\
\hline 24 & K6 & -ve & 0.00 & -ve & 0.00 & -ve & 0.00 \\
\hline 25 & K7 & -ve & 0.00 & -ve & 0.00 & -ve & 0.00 \\
\hline 26 & S1 & -ve & 0.00 & $+\mathrm{ve}$ & 16.00 & -ve & 0.00 \\
\hline 27 & S2 & -ve & 0.00 & -ve & 0.00 & -ve & 0.00 \\
\hline 28 & S3 & $+\mathrm{ve}$ & 2.00 & $+\mathrm{ve}$ & 12.00 & -ve & 0.00 \\
\hline 29 & S4 & $-v e$ & 0.00 & $+\mathrm{ve}$ & 14.00 & $+\mathrm{ve}$ & 18.00 \\
\hline 30 & S5 & $+\mathrm{ve}$ & 15.00 & $+\mathrm{ve}$ & 26.00 & $+\mathrm{ve}$ & 28.00 \\
\hline 31 & S6 & -ve & 0.00 & -ve & 0.00 & -ve & 0.00 \\
\hline 32 & S7 & $+\mathrm{ve}$ & 19.00 & $+\mathrm{ve}$ & 27.00 & $+\mathrm{ve}$ & 32.00 \\
\hline 33 & $\mathrm{Ch}$ & $+\mathrm{ve}$ & 4.00 & -ve & 0.00 & -ve & 0.00 \\
\hline 34 & $\mathrm{Ka}$ & -ve & 0.00 & $+\mathrm{ve}$ & 14.00 & $+\mathrm{ve}$ & 16.00 \\
\hline 35 & $\mathrm{~N} 1$ & $+\mathrm{ve}$ & 9.00 & $+\mathrm{ve}$ & 10.00 & $+\mathrm{ve}$ & 24.00 \\
\hline 36 & N2 & -ve & 0.00 & $+\mathrm{ve}$ & 12.00 & $+\mathrm{ve}$ & 20.00 \\
\hline 37 & N3 & -ve & 0.00 & $+\mathrm{ve}$ & 11.00 & $+\mathrm{ve}$ & 20.00 \\
\hline 38 & N4 & $+\mathrm{ve}$ & 4.00 & $+\mathrm{ve}$ & 18.00 & $+\mathrm{ve}$ & 22.00 \\
\hline 39 & $\mathrm{~N} 5(\mathrm{G})$ & -ve & 0.00 & $+\mathrm{ve}$ & 13.00 & $+\mathrm{ve}$ & 20.00 \\
\hline 40 & N5(W) & $+\mathrm{ve}$ & 6.00 & $+\mathrm{ve}$ & 16.00 & $+\mathrm{ve}$ & 24.00 \\
\hline 41 & N6 & $-v e$ & 0.00 & $+\mathrm{ve}$ & 6.00 & $+\mathrm{ve}$ & 20.00 \\
\hline 42 & N7 & -ve & 0.00 & $+\mathrm{ve}$ & 4.00 & $+\mathrm{ve}$ & 12.00 \\
\hline 43 & $\mathrm{G} 1(\mathrm{G})$ & -ve & 0.00 & $+\mathrm{ve}$ & 8.00 & $+\mathrm{ve}$ & 18.00 \\
\hline 44 & G1(W) & $-v e$ & 0.00 & $+\mathrm{ve}$ & 6.00 & $+\mathrm{ve}$ & 20.00 \\
\hline 45 & $\mathrm{G} 2$ & $+\mathrm{ve}$ & 8.00 & $+\mathrm{ve}$ & 11.00 & $+\mathrm{ve}$ & 16.00 \\
\hline 46 & G3 & -ve & 0.00 & $+\mathrm{ve}$ & 18.00 & $+\mathrm{ve}$ & 20.00 \\
\hline 47 & G4 & $+\mathrm{ve}$ & 4.00 & $+\mathrm{ve}$ & 12.00 & $+\mathrm{ve}$ & 18.00 \\
\hline 48 & A 1 & $+\mathrm{ve}$ & 5.00 & $+\mathrm{ve}$ & 20.00 & $+\mathrm{ve}$ & 16.00 \\
\hline 49 & $\mathrm{~A} 2$ & $+\mathrm{ve}$ & 8.00 & $+\mathrm{ve}$ & 24.00 & $+\mathrm{ve}$ & 22.00 \\
\hline 50 & A3 & $+\mathrm{ve}$ & 2.00 & $+\mathrm{ve}$ & 20.00 & $+\mathrm{ve}$ & 16.00 \\
\hline 51 & A4 & $+\mathrm{ve}$ & 10.00 & $+\mathrm{ve}$ & 20.00 & $+\mathrm{ve}$ & 24.00 \\
\hline 52 & A5 & $+\mathrm{ve}$ & 8.00 & $+\mathrm{ve}$ & 22.00 & $+\mathrm{ve}$ & 20.00 \\
\hline
\end{tabular}

The fungal isolates were grown on their respective agar plates containing indicator at $28 \pm 2{ }^{\circ} \mathrm{C}$

$(+)=$ Positive for lignolytic potential, $(-)=$ Negative for lignolytic potential. 


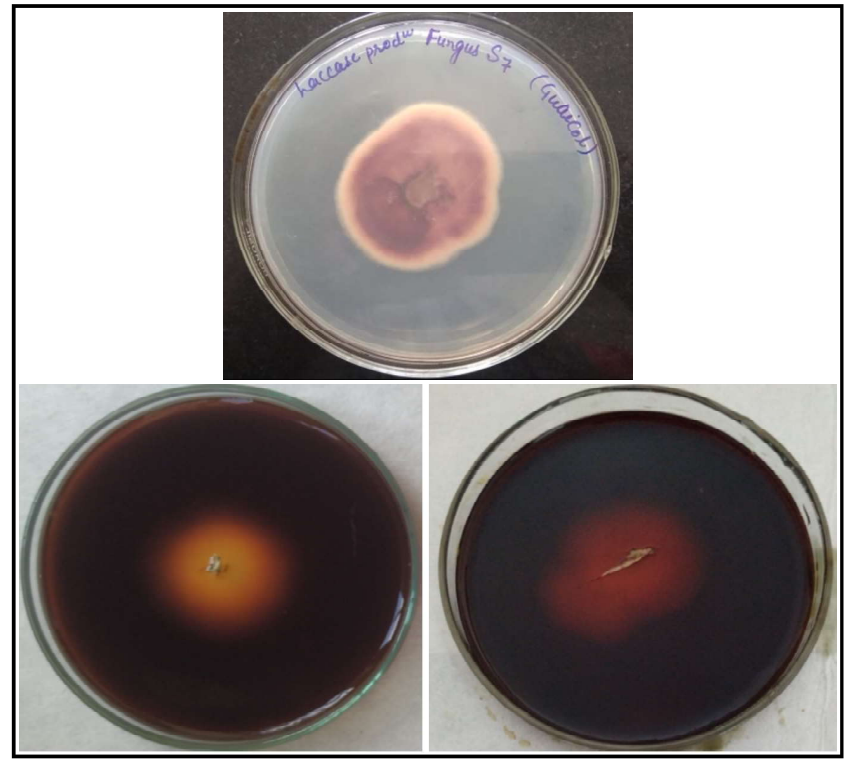

Figure 3: Qualitative screening for (a) laccase production (b) cellulase

Table 2: Quantitative screening of fungal isolates for hyperlaccase production

\begin{tabular}{|l|c|c|c|c|}
\hline Sr. No. & Isolate & Protein & \multicolumn{2}{|c|}{ Laccase enzyme } \\
\cline { 4 - 5 } & n a me & (mg/ml) & $\begin{array}{c}\text { Enzyme } \\
\text { activity*(IU) }\end{array}$ & $\begin{array}{c}\text { Specific } \\
\text { activity**(IU/mg) }\end{array}$ \\
\hline 1 & & & 0.02 & 0.03 \\
2 & R1 & 0.64 & 0.16 & 0.21 \\
3 & R5 & 0.77 & 0.01 & 0.02 \\
4 & R6 & 0.78 & 0.98 & 1.32 \\
5 & R4 & 0.74 & 0.01 & 0.02 \\
6 & SH1 & 0.63 & 0.72 & 0.82 \\
7 & SH2 & 0.88 & 0.01 & 0.02 \\
8 & C5 & 0.57 & 0.18 & 0.35 \\
9 & K3 & 0.52 & 0.10 & 0.18 \\
10 & K5 & 0.58 & 0.14 & 0.02 \\
11 & S3 & 0.61 & 0.90 & 1.19 \\
12 & S5 & 0.75 & 1.22 & 1.53 \\
13 & S7 & 0.79 & 0.01 & 0.01 \\
14 & CH1 & 0.75 & 0.02 & 0.03 \\
15 & N1 & 0.82 & 0.02 & 0.02 \\
16 & N4 & 1.07 & 0.02 & 0.46 \\
17 & N5(W) & 0.49 & 0.01 & 0.03 \\
18 & G2 & 0.49 & 0.01 & 0.01 \\
19 & A1 & 0.92 & 0.01 & 0.07 \\
20 & A2 & 0.66 & 0.00 & 0.01 \\
21 & A3 & 1.14 & 0.02 & 0.00 \\
22 & A4 & 1.25 & 0.01 & 0.02 \\
\hline & A5 & 1.02 & 0.02 & \\
\hline
\end{tabular}

*Enzyme activity (IU): $\mu$ moles of reducing sugar released $/ \mathrm{min} / \mathrm{ml}$ of enzyme **Specific activity: Enzyme activity/mg of protein.

4.2 Quantitative screening of fungal isolates for laccase, cellulase and xylanase production under submerged fermentation

The screening of hyperligninolytic fungi was exhibited in Table 2. Total 22 fungal isolates were screened for hyperlaccase production. Out of 22 isolates, four isolates showed maximum laccase activity in submerged fermentation (Figure 4). Four isolates, viz., R4, SH2, S5 and $\mathrm{S} 7$ showed highest laccase activity, i.e., $0.984 \mathrm{IU}$ with $1.32 \mathrm{U} / \mathrm{mg}$ specific activity, $0.727 \mathrm{IU}$ with $0.822 \mathrm{U} / \mathrm{mg}$ specific activity, $0.909 \mathrm{IU}$ with $1.19 \mathrm{U} / \mathrm{mg}$ specific activity and $1.226 \mathrm{IU} / \mathrm{ml}$ with $1.53 \mathrm{U} / \mathrm{mg}$ specific activity respectively and minimum enzyme activity was shown by A2 isolate, i.e., $0.009 \mathrm{IU} / \mathrm{ml}(0.073 \mathrm{U} / \mathrm{mg}$ specific activity) (Figure 5). Bisht et al. (2017) screened 15 fungal isolates quantitatively for laccase production and the highest laccase activity was shown by isolate ANF238, i.e., $3.42 \mathrm{U} / \mathrm{ml}$. An another study revealed that, twelve isolates were selected for enzyme production, out of which F6 isolate showed maximum laccase activity of $0.81 \mathrm{U} / \mathrm{ml}$ (Sakpetch et al., 2017).

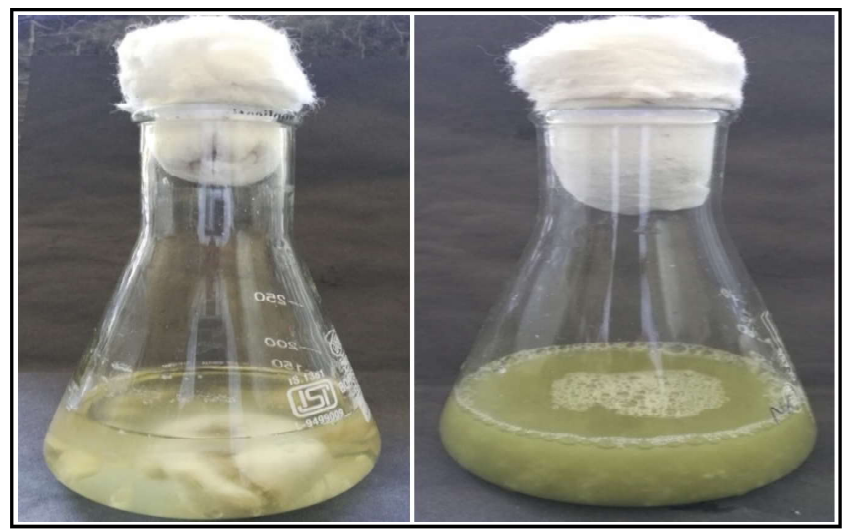

Figure 4: Hydrolytic enzyme production under submerged fermentation.

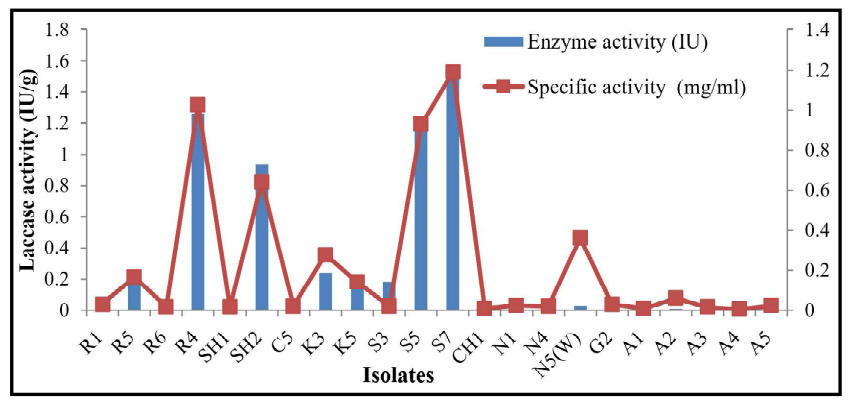

Figure 5: Quantitative screening of fungal isolates for hyperlaccase production.

Among 52 isolates, 13 fungal isolates were screened for hypercellulase production (Table 3). Out of which, four isolates showed the maximum cellulase activity. R4 showed total cellulase activity, i.e., $0.737 \mathrm{IU} / \mathrm{ml}$ with specific activity $20.47 \mathrm{U} / \mathrm{mg}$ (CMCase 0.297 , FPase $0.440 \mathrm{IU}, \beta$-glucosidase $0.007 \mathrm{IU}), \mathrm{SH} 2$ showed total cellulase activity, i.e., $0.381 \mathrm{IU} / \mathrm{ml}$ with specific activity $3.22 \mathrm{U} / \mathrm{mg}$, (CMCase $0.099 \mathrm{IU} / \mathrm{ml}$, FPase $0.28 \mathrm{IU} / \mathrm{ml}, \beta$-glucosidase $0.002 \mathrm{IU} /$ $\mathrm{ml})$, SH5 gave total cellulase activity, i.e., $0.267 \mathrm{IU} / \mathrm{ml}$ with specific activity $2.32 \mathrm{U} / \mathrm{mg}$, (endoglucanase $0.067 \mathrm{IU} / \mathrm{ml}$, exoglucanase 0.18 $\mathrm{IU} / \mathrm{ml}, \beta$-glucosidase $0.026 \mathrm{IU} / \mathrm{ml}$ ) and $\mathrm{S} 5$ showed total cellulase activity, i.e., $0.793 \mathrm{IU}$ with specific activity $5.74 / \mathrm{ml}$ (CMCase 0.438 $\mathrm{IU} / \mathrm{ml}$, FPase $0.350 \mathrm{IU} / \mathrm{ml}, \beta$-glucosidase $0.005 \mathrm{IU}$ ) whereas minimum cellulase activity was observed by $\mathrm{S} 4$, i.e., $0.099 \mathrm{IU} / \mathrm{ml}$ with 0.38 $\mathrm{mg} / \mathrm{ml}$ specific activity (Figure 6). Sakpetch et al. (2017) screened three isolates, i.e., $\mathrm{F} 6, \mathrm{~A} 2$ and $\mathrm{B} 15$ for production of cellulase enzyme and observed CMCase activity of $0.61,0.33$ and $0.21 \mathrm{U} / \mathrm{ml}$, respectively. The isolate NAB37 showed highest level of CMCase $(0.948 \pm 0.01 \mathrm{U} / \mathrm{ml})$ as well as FPase $(0.125 \pm 0.005 \mathrm{U} / \mathrm{ml})$ activity reported by Saini et al. (2017). Another study revealed that isolate HST16 showed maximum activity of FPase and CMCase, i.e., 0.026 $\mathrm{IU} / \mathrm{ml}$ and $0.006 \mathrm{IU} / \mathrm{ml}$, respectively (Tanvi et al., 2018). 
Table 3: Quantitative screening of fungal isolates for hypercellulase production under submerged fermentation

\begin{tabular}{|c|c|c|c|c|c|c|c|c|c|c|}
\hline \multirow[t]{2}{*}{ Sr. No. } & \multirow[t]{2}{*}{$\begin{array}{l}\text { Isolate } \\
\text { name }\end{array}$} & \multirow[t]{2}{*}{$\begin{array}{l}\text { Protein } \\
(\mathrm{mg} / \mathrm{ml})\end{array}$} & \multicolumn{2}{|c|}{ CMCase } & \multicolumn{2}{|c|}{ FPase } & \multicolumn{2}{|c|}{$\beta$-glucosidase } & \multicolumn{2}{|c|}{ Total Cellulase } \\
\hline & & & $\begin{array}{l}\text { Enzyme } \\
\text { activity* } \\
\text { (IU) }\end{array}$ & $\begin{array}{l}\text { Specific } \\
\text { activity** } \\
\text { (IU/mg) }\end{array}$ & $\begin{array}{l}\text { Enzyme } \\
\text { activity } \\
\text { (IU) }\end{array}$ & $\begin{array}{l}\text { Specific } \\
\text { activity } \\
\text { (IU/mg) }\end{array}$ & $\begin{array}{l}\text { Enzyme } \\
\text { activity } \\
\text { (IU) }\end{array}$ & $\begin{array}{l}\text { Specific } \\
\text { activity } \\
\text { (IU/mg) }\end{array}$ & $\begin{array}{l}\text { Enzyme } \\
\text { activity } \\
\text { (IU) }\end{array}$ & $\begin{array}{l}\text { Specific } \\
\text { activity } \\
\text { (IU/mg) }\end{array}$ \\
\hline 1 & R2 & 0.09 & 0.058 & 0.604 & 0.10 & 1.04 & 0.008 & 0.08 & 0.166 & 1.72 \\
\hline 2 & R3 & 0.042 & 0.072 & 1.71 & 0.14 & 3.50 & 0.008 & 0.20 & 0.218 & 5.19 \\
\hline 3 & R4 & 0.036 & 0.297 & 8.25 & 0.44 & 14.66 & 0.007 & 0.20 & 0.737 & 20.47 \\
\hline 4 & R6 & 0.029 & 0.077 & 2.65 & 0.15 & 7.50 & 0.003 & 0.11 & 0.230 & 7.93 \\
\hline 5 & $\mathrm{SH} 2$ & 0.118 & 0.099 & 0.90 & 0.28 & 2.54 & 0.002 & 0.02 & 0.381 & 3.22 \\
\hline 6 & SH4 & 0.031 & 0.054 & 1.80 & 0.15 & 5.00 & 0.007 & 0.23 & 0.211 & 6.80 \\
\hline 7 & SH5 & 0.115 & 0.067 & 0.60 & 0.18 & 1.63 & 0.026 & 0.22 & 0.267 & 2.32 \\
\hline 8 & C4 & 0.102 & 0.031 & 0.31 & 0.13 & 1.30 & 0.008 & 0.08 & 0.169 & 1.65 \\
\hline 9 & K1 & 0.110 & 0.091 & 0.82 & 0.24 & 2.18 & 0.002 & 0.02 & 0.333 & 3.00 \\
\hline 10 & S1 & 0.102 & 0.046 & 0.46 & 0.13 & 1.30 & 0.008 & 0.08 & 0.184 & 1.80 \\
\hline 11 & S3 & 0.107 & 0.048 & 0.48 & 0.11 & 1.10 & 0.010 & 0.098 & 0.168 & 1.57 \\
\hline 12 & S4 & 0.254 & 0.054 & 0.21 & 0.038 & 0.15 & 0.007 & 0.145 & 0.099 & 0.38 \\
\hline 13 & S5 & 0.138 & 0.438 & 3.17 & 0.35 & 2.69 & 0.005 & 0.036 & 0.793 & 5.74 \\
\hline
\end{tabular}

*Enzyme activity (IU): Moles of reducing sugar released/min/ml of enzyme.

**Specific activity: Enzyme activity/mg of protein.

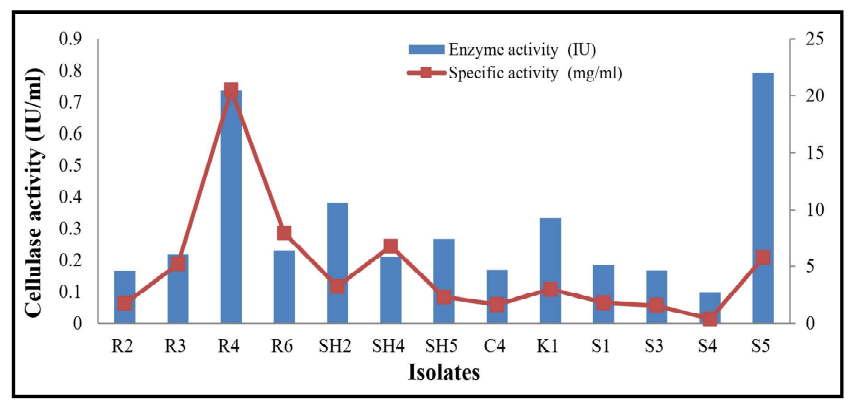

Figure 6: Quantitative screening of fungal isolates for hypercellulase production.

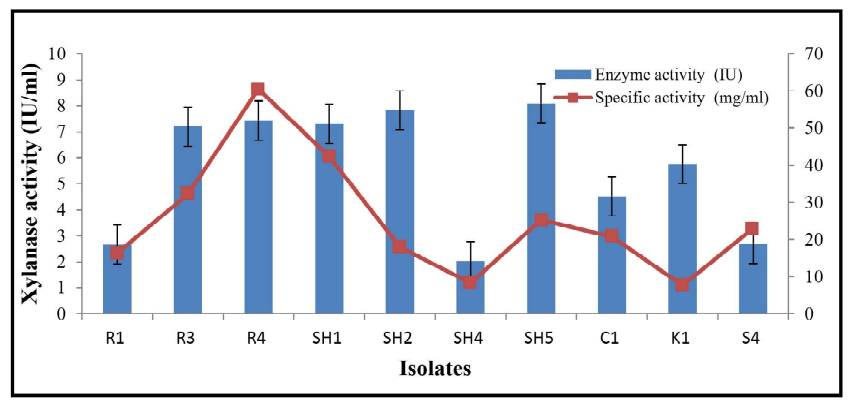

Figure 7: Quantitative screening of fungal isolates for hyperlaccase production.

10 fungal isolates were screened for hyperxylanase activity, out of which, five isolates, viz., R3, R4, S5, SH2 and SH5, showed highest xylanase activity, i.e., 7.20, 7.44, 7.31, 7.83, $8.09 \mathrm{IU} / \mathrm{ml}$ with 32.24 , $60.48,42.40,18.01,25.53 \mathrm{U} / \mathrm{mg}$ specific activities, respectively (Table 4). Minimum xylanase activity was observed by SH4, i.e., $2.03 \mathrm{IU} / \mathrm{ml}$ with $8.38 \mathrm{U} / \mathrm{mg}$ specific activity (Figure 7). Aspergillus terrus showed highest production of xylanase enzyme, i.e., $3.4 \mathrm{U} / \mathrm{ml}$ (Olanbiwoninu and Odunfa, 2016). Bisht et al. (2017) selected twelve isolates for enzyme production in LBM containing decomposed rubber bark as a carbon source. Out of 12 isolates, 3 isolates, viz., F6, A2 and B15 showed the highest enzyme activity, i.e., $0.61,0.36$ and $0.32 \mathrm{IU} / \mathrm{ml}$, respectively.
Table 4: Quantitative screening of fungal isolates for hyperxylanase production under submerged fermentation

\begin{tabular}{|l|c|c|c|c|}
\hline Sr. No. & Isolate & Protein & \multicolumn{2}{|c|}{ Xylanase enzyme } \\
\cline { 4 - 5 } & na me & $(\mathbf{m g} / \mathbf{m l})$ & $\begin{array}{c}\text { Enzy me } \\
\text { activity*(IU) }\end{array}$ & $\begin{array}{c}\text { Specific } \\
\text { activity**(IU/mg) }\end{array}$ \\
\hline 1 & & & 2.67 & 16.37 \\
2 & R1 & 0.163 & 7.20 & 32.24 \\
3 & R3 & 0.223 & 7.44 & 60.48 \\
4 & R4 & 0.213 & 7.31 & 42.40 \\
5 & SH1 & 0.172 & 7.83 & 18.01 \\
6 & SH2 & 0.435 & 2.03 & 8.38 \\
7 & SH4 & 0.243 & 8.09 & 25.33 \\
8 & SH5 & 0.319 & 4.53 & 20.85 \\
9 & C1 & 0.217 & 5.76 & 7.68 \\
10 & K1 & 0.753 & 2.70 & 22.95 \\
\hline
\end{tabular}

*Enzyme activity (IU): Moles of reducing sugar released/min/ml of enzyme **Specific activity: Enzyme activity/mg of protein.

\section{Conclusion}

In the present study, an attempt has been made for the isolation of most efficient ligninolytic, cellulolytic and xylanolytic fungi from forests of Himachal Pradesh, their screening to select hyperenzyme producing strains for industrially important enzyme production. In total, 52 fungi were isolated out of which 32 isolates were from Solan, 12 from Sirmour, 6 from Shimla and 1 each from Chamba and Kangra proceed in and around Monsoon season of Himachal Pradesh. Under submerged fermentation, these screened isolates produced laccase in the range of 0.01 to 1.22 , cellulase 0.099 to 0.793 and Xylanase 2.03 to $8.09 \mathrm{U} / \mathrm{ml}$. The maximum laccase, cellulase and xylanase activity was observed in R4, S5, SH5, and $\mathrm{SH} 2$ and found potential producer of hydrolytic enzymes which fulfill our aim of the study.

\section{Acknowledgements}

Authors gratefully acknowledge the financial support given by National Mission on Himalayan studies (NMHS), Ministry of Environment, Forest and Climate Change (MoEF\&CC), Govt. of 
India, New Delhi and G.B. Pant National Institute of Himalayan Environment and Sustainable Development (GBPNIHESD), KosiKataramal, Almora, Uttarakhand.

\section{Conflict of interest}

The authors declare that there are no conflicts of interest in the course of conducting the research. All the authors had final decision regarding the manuscript and decision to submit the findings for publication.

\section{References}

Acharya, D.K.; Chabhadiya, S.B.; Shah, J.H.; Shilpkar, P.; Acharya, P.B. and Modi, H.A. (2010). Enzyme profiling of lignocellulolytic fungi. International Journal of Biological and Chemical Sciences, 4:443-449.

Alsohaili, S.A. and Hasan, M.B. (2018). Morphological and molecular identification of fungi isolated from rotten wood samples. Sciences Letters, 11:329-337.

Barakat, A.; Mayer, C.; Solhy, A.; Arancon, R.A. and De Vries, H. (2014). Mechanical pretreatments of lignocellulosic biomass: Towards facile and environmentally sound technologies for biofuels production. Royal Society of Chemistry and Advances, 4:109-127.

Berghem, L.E.R. and Pettersson, L.G. (1973). Mechanism of enzymatic cellulose degradation and purification of a cellulolytic enzyme from $T$. viride active on highly ordered cellulose. Journal of Biochemistry, 37:21-30.

Bisht, M.; Rathi, N. and Rai, N. (2017). Importance of lignin modifying enzymes from isolated white rot fungus in lignin degradation. International Journal of Innovative Research in Science, Engineering and Technology, 6:181-188.

Chayal, S. and Agarwal, P.K. (2016). Preliminary screening for laccase producing endophytic fungi from Cupressus torulosus. International Journal of Science, Engineering and Management, 1:85-89.

Dwivedi, U.N.; Singh, P.; Pandey, V.P. and Kumar, A. (2011). Structure function relationship among bacterial, fungal and plant laccases. Journal Molecular Catalysis Biological Enzyme, 68:117-128.

Ferdes, M.; Dinca, M.; Zabava, B.; Paraschiv, G.; Munteanu, M. and Ionescu, M. (2018). Laccase enzyme production and biomass growth in liquid cultures of wood degrading fungal strains. Simposijium "Actual Tasks on Agricultural engineering”, Optaija, Croatia, 4:341-348.

Gomez, K.A. and Gomez, A.A. (1976). Statistical procedures for agricultural research ( $2^{\text {nd }}$ ed.) John Wiley and Sons, Singapore, pp:920.

Kalra, K.; Chauhan, R.; Shavez, M. and Sachdeva, S. (2013). Isolation of laccase producing Trichoderma sp. and effect of $\mathrm{pH}$ and temperature on its activity. International Journal of Chemistry Environmental Technology, 5:2229-2235.

Kaur, A. and Gupta, U. (2016). Isolation and qualitative selection of fungi for production of lignocellulolytic enzymes. International Journal of Current Microbiology and Applied Sciences, 5:718-730.
Lowry, O.H.; Rosebrough, N.; Farr, A.L. and Randall, R.J. (1951). Protein measurement with the Folin-phenol reagent. Journal of Biology and Chemistry, 193:265-275.

Mahmood, R.A.; Muhammad, J.A.; Muhammad, A.; Muhammad, G.; Dawood, A.; Pervez, A. and Nasib, Z. (2016). Isolation of indigenous brown rot fungi from rotten wood from selected areas of Pakistan. Journal of Advances in Biology and Biotechnology, 10:1-8.

Miller, G. L. (1959). Use of dinitrosalicylic acid reagent for determination of reducing sugars. Analytical Chemistry, 31:426-428.

Megersa, D.; Mashilla, D. and Wende, A. (2017). Management of turcicum leaf blight [Exserohilum turcicum Leonard Suggs] of maize (Zea mays L) through interaction of host resistance and fungicide at Bako, Western Ethopia. African Journal of Plant Sciences, 11:6-22.

Nagraj, A.K.; Singhvi, M.A.; Kumar, V.R. and Gokhale, D.A. (2014). Optimization studies for enhancing cellulase production by Penicillium janthinellum mutant EU2D-21 using response surface methodology. Bioresources, 9:1914-1923.

Nayak, B.; Choudhary, R. and Royman, M.G. (2017). Lignocellulolytic fungal isolation and screening for the laccase producing ability. Indian Journal of Science and Research, 13:188-191.

Olanbiwoninu, A.A. and Odunfa, A.S. (2016). Production of cellulase and xylanase by Aspergillus terreus KJ829487 using cassava peels as subtrates. Advances in Microbiology, 6:502-551

Ramanjaneyulu, G.; Reddy, K.R.; Kumar, D.K. and Reddy, R.B. (2015). Isolation and screening of xylanase producing fungi from forest soils. International Journal of Current Microbiology and Applied Sciences, 4:586-591.

Reese, E.T.; Mandel, M. (1963). Enzymatic hydrolysis of cellulose and its derivatives in: Method carbohydrate chemistry, whistles RL, Eds. pp:139-143, Academic Press; London.

Rehan, A.M.; Hassan, E. and Ramadan, E. (2016). Production of laccase enzyme for their potential application to decolorize fungal pigments on aging paper and parchment. Annals of Agricultural Sciences, 61:1-11.

Saini, A.; Agagarwal, N.K. and Yadav, A. (2017). Isolation and screening of cellulose hydrolyzing bacteria from different ecological niches. Bioengineering and Bioscience, 5:7-13.

Sakpetch, P.; Kittikiun, A. and Chandumpai, C. (2017). Isolation and Screening of potential lignocellulolytic microorganisms from rubber bark and other agricultural residues. Walailak Journal of Science and Technology, 14:34-39.

Sreedevi, S.; Sajith, S. and Benjamin, S. (2013). Cellulase producing bacteria from the wood-yards on Kallai river bank. Advanced Microbiology, 3:326-332.

Vantamuri, A.B. and Kailwal, B.B. (2015). Isolation, screening and identification of laccase producing fungi. International Journal of Pharma and Bio Sciences, 6:242-250.

Citation: Dimple Tanwar, Nivedita Sharma, Nisha Sharma and Prashant Kumar Prusty (2020). Isolation and screening of fungi from rotten wood for various hydrolytic enzymes production. Ann. Phytomed., 9(1):122-128. http://dx.doi.org/ 10.21276/ap.2020.9.1.15 